\title{
Erratum to: Organizational leadership in Central Asia and the Caucasus: Research considerations and directions
}

\author{
Kiran M. Ismail • David L. Ford Jr.
}

Published online: 5 June 2010

(C) Springer Science+Business Media, LLC 2010

Erratum to: Asia Pac J Manag (2010) 27:321-340

DOI 10.1007/s10490-008-9130-3

The original version of this article unfortunately missed some data on the biography of Dr. Kiran M. Ismail. The complete biography is as follows:

Kiran M. Ismail ( $\mathrm{PhD}$, University of Texas at Dallas) is an assistant professor of Management at St. John's University. Her research centers on business, leadership and management in transition economies, inter- and intra-organizational social networks, and organization behavior and human resource management issues associated with intra-organizational relationships, including leader-subordinate relationships.

The online version of the original article can be found at doi:10.1007/s10490-008-9130-3.

K. M. Ismail $(\bowtie)$

The Peter J. Tobin College of Business, St. John's University, 8000 Utopia Parkway, Queens, NY 11439, USA

e-mail: ismailk@stjohns.edu

D. L. Ford Jr.

School of Management, The University of Texas at Dallas, Richardson, TX 75083-0688, USA

e-mail:mzad@utdallas.edu 